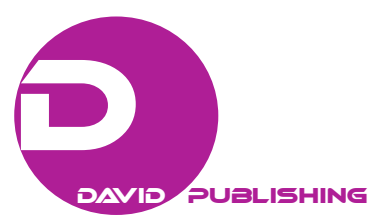

\title{
Michel Houellebecq: The Era of Emptiness
}

\author{
Ruth Amar \\ University of Haifa, Haifa, Israel
}

\begin{abstract}
Michel Houellebecq is perhaps the most successful, the most famous and controversial of all current novelists writing in French. He has become a global publishing phenomenon: His books have been translated worldwide, film adaptations of his novels have been produced, and the author is the subject of a million-euro publishing deals and successive media scandals in France. The novels depict surprising forms of imaginary resources, a radiating end of the world, a post-nuclear anxiety, and depressive characters. Houellebecq shocks us leaving us in a world where the feelings of love, tenderness and goodwill have disappeared. The purpose of Houellebecq's novels is to alert about the real problems of the human society in the twenty-first century. Indeed, in the books we can easily recognize the essential features of contemporary society and the fact that the individual assumes a dehumanization process in which one has to cope with his solitude in a world of emptiness. This socio-cultural dimension is indeed the background of Houellebecq's novels, novels in which the protagonists seem to be wedged in a mechanism from which it is difficult to escape: reification and dehumanization on the one hand, "robotization" of love on the other. This article focuses on the analysis of the texts revealing the poignant characteristics of "L'Ère du vide" ("The Era of Emptiness") as described by Gilles Lipovetsky: Loneliness, the lack of love and its replacement by sexual relations.
\end{abstract}

Keywords: reification, dehumanization, "robotization", "L'Ere du vide”, loneliness, lack of love, sexual relations

Michel Houellebecq is a critically divisive figure in the French literary landscape. Much has been said about him, on his work a little less, except that it contains the perfect contemporary cynicism catalog or the anthology of the contemporary society's failures. He is perhaps the most successful and controversial of all current novelists writing in French. Houellebecq has become a global publishing phenomenon: His books have been translated worldwide, film adaptations of his novels have been produced, and the author is the subject of a million-euro publishing deals and successive media scandals in France. If Houellebecq is unique in the contemporary French writing, it is due not only to his extraordinary success, but also to the incomparable scope of his narrative ambition. Both Houellebecq and his novels attract the news and Television as Houellebecq does not hesitate to give interviews in spite of his countenance of a shy person. Houellebecq's media persona, which has frequently masked critical readings of his work, is brought to bear a derisive self-portrait within his writing, particularly in the Prix Goncourt-winning La Carte et le territoire (The Map and the Territory).

Considered as the most controversial French novelist in decades Houellebecq attacks everything the 60's generation holds dear and bursts the frames of auto-fiction of the French way to become the novelist of globalization. As a novelist and a metaphysician who questions the relationship between sex and death in post-modernity, he also reveals the dramatic crisis of filiation. Undoubtedly, one of the most trenchant satirists 
of our time, Houellebecq reduces the projected utopias and his work is a reflection of the social and economic reality of life in a post-industrial society. Houellebecq shows a world of violence and tension, a world where people find it hard to be at ease, so that life becomes a process of disease.

Bruno Viard suggests that Houellebecq uses two distinct narrative voices. Already in his article on Houellebecq in 2004, he states:

Il y a donc deux voix enchevêtrées dans ces romans : celle d'un moraliste austère qui a fait bondir tous ceux qui sortent leur pistolet dès qu'on parle de morale, d'autre part celle d'un grand névrosé qui ne pense qu'à se faire sucer la queue par toutes les petites garces de passage. (Viard, 2004, p. 130)

According to Olivier Bardolle, Houellebecq is the only writer who reflects the contemporary era with accuracy, as Proust and Celine were the warrants of their time. John McCann, in Michel Houellebecq: Author of Our Times confirms that Houellebecq has put the humour back into the Absurd, without losing any of the awareness and the bleakness of the human condition. He states that Houellebecq is "derivative" in the best sense of the word, that "reminds us that what we encounter is not created out of nothing but always comes from somewhere" (McCann, 2010, p. 5). He argues that this consuming obsession with the past finds its most complete expression in the clones of La Possibilité d'une île (The Possibility of an Island) whose entire lives are devoted to reading and re-reading the life history of their predecessors, thereby ironically achieving the aspiration of the Extension du domaine de la lutte's narrator: "une vie entière à lire". Douglas Morrey in Michel Houellebecq: Humanity and its Aftermath, offers an extensive analysis of the provocative social questions raised in Houellebecq's work. In Morrey's assessment, Houellebecq's insight into contemporary human condition is essential: It gives the reader the opportunity "to see ourselves in a new light" (Morrey, 2013, p. 153). Morrey argues that the narrating voices present their social analysis from a point beyond the extinction of humankind, which legitimizes his texts' extensive sociological and historical contextualization.

Carole Sweeney, in Michel Houellebecq and the Literature of Despair, explains the effects of autonomous capitalism as it extends into all areas of life including sexuality, emphasizing that for Houellebecq, there are only two possible responses to this aggressive seizure: hedonisim and ascetic withdrawal. She states that a biotechnical, post-human solution to capitalism's power is "no world at all" (p. 190).

Houellebecq questions traditional notions of humanity through radical posthumanist position. His novels narrate a metaphysical mutation or a paradigm shift through which humanity, as we know it ceases to be the main value or motivation of our world when it comes into conflict with a competitor in the form of a post-human or neo-human species.

Houellebecq's novels depict surprising forms of imaginary resources, a radiating end of the world, a post-nuclear anxiety, and depressive characters. There is an attempt of liquidation. Ferociously, sadistically, Houellebecq shocks us leaving us in a world where the feelings of love, tenderness and goodwill have disappeared. The strength of a direct, "flat" style, some have baptized "non-style" imposes on other styles of his time. At wondering about this question, Dominique Noguez explains that Houellebecq is "au cœur de maintes synthèses et cicatrisations: un dépressif qui oublie souvent d'être asthénique, un réaliste lyrique, un indifférent qui s'indigne, un doux qui cogne" (Noguez, 2003, p. 154). In doing so, he highlights the fact that it is impossible to detach Houellebecq's style from the content of his novels, novels that tell the new socio-emotional era. The elegance of his precise solutions and a utopian or rather dystopian design. And a lot of humor too. 
Nevertheless, behind the humor lies the purpose of Houellebecq's novels: It is high time to alert about the real problems of the human society in the twenty-first century. Indeed, in the books we can easily recognize the essential features of contemporary society and the fact that the individual assumes dehumanization problems. This is a work where, as Dominique Viart puts it: "Le pessimisme domine 1'œuvre de Michel Houellebecq, face à une civilisation occidentale dont il ausculte les névroses obsessionnelles et les pathologies" (Viart \& Vercier, 2005, p. 348). However, the most dramatic problem is that the individual has to cope with his solitude in a world of emptiness:

Mais rien en vérité ne peut empêcher le retour de plus en plus fréquent de ces moments où votre absolue solitude, la sensation de l'universelle vacuité, le pressentiment que votre existence se rapproche d'un désastre douloureux et définitif se conjuguent pour vous plonger dans un état de réelle souffrance. (Houellebecq, 1994, pp. 12-13)

In La Littérature sans estomac Pierre Jourde asserts that Houellebecq's novels are «des textes au réalisme ambitieux, où les considérations sexuelles et politiques font partie intégrante d'un projet de mise en scène globale, à travers le portrait de vies très ordinaires, des problèmes du monde contemporain» (Jourde, 2002). This socio-cultural dimension is indeed the background of Houellebecq's novels, novels in which the protagonists seem to be wedged in a mechanism from which it is difficult to escape: reification and dehumanization on the one hand, "robotization" of love on the other. As Jourde putsits: Houellebecq's texts are «des textes au réalisme ambitieux, où les considérations sexuelles et politiques font partie intégrante d'un projet de mise en scène globale, à travers le portrait de vies très ordinaires, des problèmes du monde contemporain» (Jourde, 2002). The texts reveal the most poignant characteristics of "L'Ere du vide" as described by Gilles Lipovetsky: loneliness, the lack of love and its replacement by sexual relations.

\section{Loneliness and Alienation}

Houellebecq's novels focus on the contemporary society, a society that displays the reification of human relations and the fact that the individual is asocial, lonely and unable to communicate with the other. It reminds strongly the way Lipovetsky describes the newpersonal relationships: "C'est à un détachement émotionnel qu'aspireraient de plus en plus les individus, en raison des risques d'instabilité que connaissent de nos jours les relations personnelles" (Lipovetsky, 1983, p. 109). Indeed, several studies highlighting the influence of the individuation development in the late twentieth century show that it has serious human consequences: Gilles Lipovetsky's L'Ère du vide (The Era of Emptiness) reveals how the post-modern Western human being experiences his solitude, undergoes separation and is no longer able to assume an external communication. Loneliness is progressively widening since the subject is not the human being anymore, not even the human race, but rather a world in which human beings are dehumanized and materialized in a capitalist society. ${ }^{1}$ Man has lost his own image as a creature centered on itself; he has ceased to be a human being with a spiritual center founded on its inner continuity and personal unity. The image of a complete, unified man has disappeared, giving way to non-human aspects. All that remains of him are some of his functions. These new conditions of the human being are present in the contemporary novel, in modern science and philosophy. ${ }^{2}$ Lipovetsky

\footnotetext{
1 As set in the Marxist theory.

${ }^{2}$ Regarding this subject, please refer to Nicolas Berdyaev's book, The Fate of Manin the Modern World, University of Michigan Press, 1969; a historic-philosophical essay that studies the human being existence as a historical existence. History never resolves the conflict between the individual and society, the individual and civilization. The individual is active in the history and creates it. This way, his personality develops, but history is cruel towards the human being. History is, in fact, the fall of man and his dreams that do not always come true.
} 
argues:

Il n'est pas vrai que les individus recherchent un détachement émotionnel et se protègent contre l'irruption du sentiment, a cet enfer peuplé de monades insensibles et indépendantes, il faut opposer les clubs de rencontres, les «petites annonces », le «réseau», tous ces milliards d'espoirs de rencontres, de liaisons, d'amour, et qui précisément sont de plus en plus difficilement réalisés. (Lipovetsky, 2003, p. 111)

These hopes and attempts of meeting the other in Houellebecq's novels, are labeled by Olivier Bardolle in terms of "la bénédiction de l'Ère du vide" ("the benediction of the Era of emptiness") (Bardolle, 2002, p. 48). They reveal marginal protagonists with meaningless livelihood. In Extension, employees are reduced to their worthless efforts when fighting for technocratic objectives. The narrator is a symbol of this vital exhaustion. His name is never mentioned, referring to the fact that he is supposed to be any individual, a fact that finally leads simultaneously to his reification. "Pas de sex, pas d'ambition; ni de Distractions réelles". ${ }^{3}$ From the first pages of the story, we are faced with a marginal character for whom solitude has become "douloureusement tangible" (Houellebecq, 1994, p. 9) and who "fréquente peu les êtres humains [...] Les relations humaines deviennent progressivement impossibles..." (Houellebecq, 1994, p. 16). He is often submerged in situations where solitude and "la sensation de l'universelle vacuité, le pressentiment que votre existence se rapproche d'un désastre douloureux et définitif” (Houellebecq, 1994, p. 13) lead him to a real state of suffering. Finally he states that the priest with whom he has some relation considers him as "un symbole pertinent de cetépuisement vital. Pas de sexualité, pas d'ambition, pas vraiment de distraction, non plus" (Houellebecq, 1994, p. 32).

However, in the Extension we witness the fact that the narrator is not the only protagonist to be alone. Other characters in the novel too are miserable solitary figures. For instance, the only girl of the narrator's adolescence named ironically Brigitte Bardot is described as a person who has "pas d'amies, niévidementd'amis, elle était donc parfaitement seule. Personne ne lui adressait la parole, même pour un exercice de physique, on préférait toujours s'adresser à quelqu'un d'autre" (Houellebecq, 1994, p. 83). As the narrator's only friend, the priest becomes depressed after an abortive relationship. He, who used to encourage the narrator out of loneliness and to seek God, is finally disheartened and suddenly loses not only hope but also his faith: "Demain, il vafalloir que je dise la messe. Je ne vais pas y arriver. Je ne pense pas pouvoir y arriver. Je ne sens plus la présence" (Houellebecq, 1994, p. 140). With regard to Tisserand, the colleague working with the narrator, who always tries to break the blockade of the women's rejection, loneliness is caused by his enormous continuously suppressed desire. The way in which this problem is described is summed by Houellebecq in an interview:

Malheureusement, dans le cas de Tisserand, ce n'est pas la publicité qui fait son malheur, c'est l'attractivité sexuelle inouïe de certaines jeunes filles (et son propre manque d'attrait). Qu'y faire ? Quelle société pourrait résoudre cette question? Sincèrement, je ne vois pas. (Machado da Silva, 2003).

A few years later, facing the loneliness of Extension, another kind of loneliness rises up that drives Les Particules Elementaires's (in English it was translated to Atomised) protagonists to the inevitable fiasco. Thus, recurring motifs appear in Houellebecq's oeuvre that prove how hard it is for the individuals to transcend this opaque and scary stage of human evolution. While the protagonist of the Extension toggles into depression, Bruno of the Particules goes insane and Michel commits suicide. However, the difference seems to be in the

\footnotetext{
3 extension.
} 
solution to human afflictions at the end of the second novel that did not exist in the first. The answer comes at the end of the Particules when the novel capsizes in science fiction. As the story progresses in the 2050s, the issue of sexuality is solved by the discovery of the gene by Michel Djerzinsky: with the help of the genetic cloning, "l'humanité devait disparaître; l'humanité devait donner naissance à une nouvelle espèce, asexuée et immortelle, ayant dépassé l'individualité, la séparation et le devenir"”.

The frightening aspect of alienation is accentuated by the solution of suicide as conceived by the human being of the 21 st century. In addition to the genetic cloning solution, another dimension accentuates the human being's sheer loneliness. It expresses the will of a final solution for the daily anguish of the human being in a time when it seems that it is more and more difficult to have contact with each other, as Gilles Lipovetsky puts it:

Plus la ville développe les possibilités de rencontre, plus les individus se sentent seuls; plus les relations deviennent libres, émancipées des anciennes contraintes, plus la possibilité de connaître une relation intense se fait rare. Partout on retrouve la solitude, le vide, la difficulté à sentir, à être transporté hors de soi. (Lipovetsky, 1983, p. 111)

The self-destructive act that is one of the most tragic consequences of the modern man's loneliness appears repeatedly in H's work. It expresses the will of a final way out for the daily torment of the human being in a time when interaction between men seems more and more difficult. Reflecting the hostile symptoms of the postmodern society, Houellebecq's work accentuates not only homicide ${ }^{5}$ but also suicide. The self-destructive act is one of the most tragic consequences of loneliness that emerge repeatedly in the work: in Extension, Tisserand is killed in a car accident after he fought "jusqu'au bout [...] dans son cœur il y avait encore la lutte, le désir et la volonté de la lutte" (Houellebecq, 1994, p. 121); in the Particules Michel Djerzinsky once he has completed his research, "se sentantdépourvu de toute attache humaine [...] est entré dans la mer" (Houellebecq, 1998, p. 378). Annabelle after she realizes she is suffering from an incurable cancer, decides to end her life, also putting an end to the opportunity for Michel to know love, "car il avait pu, par l'intermédiaire d'Annabelle, s'en faire une image" (Houellebecq, 1998, p. 377). Christiane, Bruno's companion, commits suicide after her accident during a violent orgy, after which she remains paralyzed.

The narrator supports this act, making it legitimate by evoking the two famous philosophers' suicides—Deuleuze and Debord:

Cet examen rationnel des jouissances et des douleurs, que chacun, tôt ou tard, est conduit à faire, débouche inéluctablement à partir d'un certain âge sur le suicide. Il est à ce propos amusant de noter que Deuleuze et Debord, deux intellectuels respectés de la fin du siècle, se sont l'un et l'autre suicidés sans raison précise, uniquement parce qu'ils ne supportaient pas la perspective de leur propre déclin physique. (Houellebecq, 1998, p. 308).

Four years later, the five hundred pages of La Possibilité contribute to the evolution of the oeuvre in the same direction, now convoyed by a fascinating parade. Tired of his empty existence without purpose, Daniel 1 states: "J'étais un observateur acéré de la réalité contemporaine". Like his son, he too commits suicide. Nevertheless, this time successive reincarnations of neo-humans with genetic mutation solutions will follow. However, we recognize Daniel 1 the protagonist who strongly resembles the computer engineer obsessed by miniskirts of Extension and Bruno, the protagonist harassed by panties of the Particules. It appears that for the characters, the anguish of death is secondary to that of existence, so that the sinister idea of suicide is a

\footnotetext{
4 Ibidem, p. 385.

${ }^{5}$ In Extensiondu domaine de la lutte, the narrator urges Raphael to the raciste murder of his sexual black competitor.
} 
logical—or even an easier- solution.

Expressed in this manner, the characteristics of the postmodern solitary human being are dreadful: the dismantling of the personality, the exile of the self and the abduction of the soul; the sinister idea of suicide is introduced in the stories to highlight the most painful picture of the lonely members of the post-modern society. It seems that for the characters, solitude is incurable, and the anguish of death compared to that of life is a logical, easy solution.

\section{The Loss of Love and its Replacement by Sex}

Deriving from the problem of solitude, love has become practically impossible. In the novels it has changed from a valuable experience to a scarce and artificial phenomenon. When asked about love in an interview, Houllebecq proclaims:

J'ai toujours affirmé, dans mes livres, que l'amour existe, ne serait-ce que parce que l'on peut en constater les échecs [...] Dans Les particules élémentaires, j'affirme - et je le maintiens - que l'homme n'est pas capable d'aimer. Il recherche beaucoup plus une reconnaissance sexuelle (Unruh).

The phenomenon of human relations as we have seen, leads to an automation of love on the part of the protagonists. According to Murielle Lucie Clément the protagonists do not know how to deal with love: "Rencontrent-ils ce qui pourrait devenir de l'amour, qu'aussitôt la terre promise s'éloigne dans la violence mortifère d'une tourmente aussi brutale qu'irrémédiable dont les ressors déclencheurs s'enracinent souvent dans l'abject" (Clément, 2003, p. 130). These tragic aspects of the postmodern society are expressed in the work in different manners in the novels. The texts form a thematic arc showing a movement away from human emotions. First, it is obvious that scientific progress and intellectual talents drive away from emotions. Regarding Michel in Atomized: "Depuis des années, Michel menait une existence purement intellectuelle. Les sentiments qui constituent la vie des hommes n'étaient pas son sujet d'observation, il les connaissait mal" (Houellebecq, 1998, p. 119). Secondly, sexual consumption is accompanied by a robotization of intimate feelings and thus, of love. This phenomenon is manifested in what Houellebecq calls the "Venus system", a feminine system "basé sur la séduction et le sexe" (Houellebecq, 1994, p. 147). It suggests that sexual alienation caused by the reification of interpersonal relationships is one of the major problems of contemporary society.

[...], les hommes de sa génération passèrent en outre leur vie dans la solitude et l'amertume. Les sentiments d'amour, de tendresse et de fraternité humaine avaient dans une large mesure, disparu, dans leurs rapports mutuels ses contemporains faisaient le plus souvent preuve d'indifférence, voire de cruauté. (Houellebecq, 1998, p. 7)

Another aspect of this movement away from emotion is the inactiveness of the protagonists. After Annabelle's death, it seems first that Michel will need love. However, it is said "Lui-même ne demandait qu'à aimer, du moins il ne demandait rien. Rien de précis"6. "Nothing specific" means he has really nothing genuine to give or any desire to promote himself in the direction of love or any commitment. He is not ready to make any effort. He reminds us of Meursault in Camus' L'Étranger, who agrees to marry Mary only because she asks him to. This passivity or even indifference is what kills love.

What is likely to have the upper hand finally, is "sex consumption" devoid of love. The most significant development that emerges from the novels is that alongside the economic liberalism of the sixties, Houellebecq

${ }^{6}$ Ibid.p. 119. 
unfolds the "liberalismesexuel" which certainly teases what others have called the "revolution sexuelle". Since then, the two areas of competition control all other social aspects and have amplified so as to invade "tous les âges de la vie [...] et toutes les classes de la société" (Houellebecq, 1994, p. 100), hence the title of the novel: "Extension du domaine de la lutte" (Extension of the fight domain translated in English into Whatever) The protagonist, uses the condensed formula to announce the new phenomenon: "La sexualité est un système de hierarchie sociale" (Houellebecq, 1994, p. 93). Sex against economy. Sex against gender. Sex against melancholy and emptiness. But sex is not always an easy task: it must be efficient, as competition between individuals is fierce. The narrator of the Extension presents a theory: sex is indeed a second differentiation system and it behaves like "un système de différentiation au moins aussi impitoyable" (Houellebecq, 1994, p. 100). The effects of these two systems are equivalent, "tout comme le libéralisme économique sans frein, et pour des raisons analogues, le libéralisme sexuel produit des phénomènes de paupérisation absolue" (Houellebecq, 1994, p. 100), where sexual activity (which can be described as pornographic) is a battlefield, where the characters are obsessed with orgasms and ejaculations. The moments of sexual pleasure are brief and are the only potential form of transcendence.

Thus, the sexual consumption paralleled with financial consumption runs the life of the protagonists: some are winners, other are defeated. In the Extension and the Particules Elémentaires, it is no doubt the beaten people Houellebecq chooses to describe. Echoing the microcosm failure of Michel and Bruno, the failure of the consumer society without predominant cultural values, is revealed in the macrocosm-morbid symptoms of the era of emptiness. While Michel confined in science, is driven to a genetic solution of humanity but also to its destruction, Bruno's abusive sexual relations are undoubtedly a reaction against the postmodern conditions and simultaneously, a journeytowards madness.

In his Possibilitéd'une ile, Houellebecq goes much further; it is not an "extension du domaine de la lutte" anymore but a genetic mutation that leads the human being to the "post-human", an era where sexuality and love as they exist today are step by step abolished and substituted by an automation of the sexual act (this act being the only remaining happy illusion of contemporary life): "L'intérêt que notre société feint d'éprouver pour l'érotisme ... est tout à fait factice" (Houellebecq, 1994, p. 31). In fact, most people, are quickly bored by the subject "mais ils prétendent le contraire, par une bizarre hypocrisie à l'envers" (Houellebecq, 1994, p. 31). Thus for the neo-humans, love as other emotions, have remained only as a text they can read in the ancient human species' (their ancestors) journals.

Although we have dealt with the era of emptiness and the manner it is reflected in Houellebecq's oeuvre, we should also remind that now and then, glimpses of hope appear on the background of the daily depressive characters. It is precisely the few moments of profound truth such as those where Bruno confesses to Christiane: "Je crois que je suis heureux ${ }^{7}$ and where Daniel 1 states: "Pour la première fois de ma vie je me sentais, sans restrictions, heureux d'être un homme" ${ }^{8}$. This is not the first time that the question of happiness upsurges in the oeuvre. In 1997, Houellebecq published his collection of poems: La Poursuite du bonheur, and the word appears here and there through the work, often in verses included in his prose (Houellebecq, 2005, p. 15).

According to Dominique Noguez, the idea of happiness introduced in the texts of Houellebecq is due to the influence of the writings of Auguste Comte, the father of positivism. And this sentence reflects Comte's idea on happiness:

\footnotetext{
7 Michel Houellebecq, Les Particules élémentaires, Paris, Flammarion, 1998, p. 276.

${ }^{8}$ Michel Houellebecq, LaPossibilité d'une île, Paris, Fayard, 2005, p. 221.
} 
Au milieu des plus graves tourments qui puissent jamais résulter de l'affection, je n'ai jamais cessé de sentir que l'essentiel pour le bonheur c'est toujours d'avoir le cœur dignement rempli, même de douleur, oui même de douleur, de la plus amère douleur (Comte).

Pain is also part of the progress towards happiness. This happiness is certainly connected to sexual pleasure "l'unique objectif en vérité de l'existence humaine, et tous les autres ne sont que des compensations dérisoires et désespérées" and all the others are just "ridiculous and desperate compensations" the pursuit of happiness is present in the work even though La Possibilité d'une ile ends in despair, facing the "impossibility of an island": "Le Bonheur n'était pas un horizon possible" (Houellebecq, 2005, p. 485).

Is there any solution to the socio-affective problems as we have just seen them? In the development of Houellebecq's work, we see a renovation: the sexual competitor of the Particules Elémentaires is no longer supposed to die (like the black competitor of the Extension) but he perishes without leaving traces as there is a solution to the miserable situation of the human being: The extirpation of desire through cloning. A cold, sharp solution: sex is definitively eradicated and replaced by a new system carefully described: the enjoyment will be provided individually by the multiplication of particles on the surface of the clitoris and the glans "offrant ainsi, dans l'économie des plaisirs, des sensations érotiques nouvelles et presque inouïes" ". The Particules put the last touches on to the first novel by its utopian solution: the production of a new society where sexual competition is no longer applicable; this outcome allows humanity to demolish the old foundations on which it was erected for millennia.

Indeed, in La Possibilité d'une île, Houellebecq a new horizon is built where the novel toggles in the world of science fiction as well as in that of Utopian fiction, while never forgetting the old human being's friend: Fox the dog: "Pour moi, je continuais, dans la mesure du possible, mon obscure existence de singe amélioré, et mon dernier regret serai d'avoir été la cause de la mort de Fox, le seul être digne de survivre... " (Houellebecq, 2005, p. 484).

\section{References}

Auguste Comte. (n.d.). “Dernière lettre à Clotilde de Vaux”, Les Maximes d'Auguste Comte. Retrieved from http://membres.lycos.fr/clotilde/maxcomte.htm?

Bardolle, O. (2002). La Littérature à vif (le cas Houellebecq), (Vivid Literature: Houellebecq Case). L'esprit des péninsules.

Clément, M. L. (2003). Houellebecq, sperme et sang (Houellebecq, Sperm and Blood). L'Harmattan.

Houellebecq, M. (1994). Extension du domaine de la lutte (Watever). Paris: Maurice Nadeau.

Jourde, P. (2002). La littérature sans estomac (Literature without Stomach). L'esprit des péninsules.

Lipovetsky, G. (2003). L'Ere du vide, Essais sur l'individualisme contemporain (The Era of Emptiness, Essay on Contemporary Individualism). Paris: Gallimard.

Machado Da Silva, J. (2003). Michel Houellebecq: Le roman comme art de la provocation. Retrieved from http://fr.wikipedia.org/wiki/Michel_Houellebecq

McCann, J. (2010). Michel Houellebecq: Author of our times. Oxford and Bern: Peter Lang.

Morrey, D. (2013). Michel Houellebecq: Humanity and its Aftermath, Michel Houellebecq: Humanity and its Aftermath. Liverpool University Press.

Noguez, D. (2003). Houellebecq en fait (Houellebecq, in Fact). Fayard.

Unruh, B. S. S. (n.d.). Conversation avec Michel Houellebecq sur le bonheur, l'échec de l'amour et la petite différence. Retrieved from http://www.houellebecq.info/revuefile/33_Epart.PDF.

Viard, B. (2004). Houellebecq du côté de Rousseau (Houellebecq and Rousseau). Amsterdam/New York: Rodopi.

Viart, D., \& Vercier, B. (2005). La Littérature française au présent (French Literature at Present). Paris: Bordas.

\footnotetext{
${ }^{9}$ Michel Houellebecq, Les Particules élémentaires, Paris, Flammarion, 1998, p. 389.
} 